\title{
Nasal mucosa in workers exposed to formaldehyde: a pilot study
}

\author{
M Boysen, E Zadig, V Digernes, V Abeler, A Reith
}

\begin{abstract}
This study evaluates the histological changes, especially the presence of possible precancerous lesions, in the nasal mucosa of workers exposed to formaldehyde. Nasal biopsies of 37 workers occupationally exposed to formaldehyde for more than five years and 37 age matched referents showed a higher degree of metaplastic alterations in the former group. In addition, three cases of epithelial dysplasia were observed among the exposed. These results indicate that formaldehyde may be potentially carcinogenic to man. Combination of this finding with the inconclusive epidemiological studies suggests that formaldehyde is a weak carcinogen and that occupational exposure to formaldehyde alone is insufficient to induce nasal cancer.
\end{abstract}

The inhalation of formaldehyde has been shown to induce squamous cell carcinoma in the nasal cavity of rats at exposure levels ranging from 6 to $14.3 \mathrm{ppm}^{12}$ and mice at an exposure level of $14.3 \mathrm{ppm} .{ }^{3}$ Although these findings aroused considerable concern about the possible long term effects in man, epidemiological studies conducted to date have not provided unequivocal evidence that exposure can induce nasal or other types of cancer. ${ }^{45}$

Like most other types of epithelial malignancies, it is reasonable to assume that nasal cancer is preceded by preneoplastic states and that the prevalence of such lesions is considerably higher than that of cancer. Experimental studies have shown that animals exposed to formaldehyde concentrations of $2 \mathrm{ppm}$ or more develop dysplasia and metaplasia of

Department of Otolaryngology, National Hospital, University of Oslo, Oslo, Norway

$M$ Boysen, E Zadig

Dyno Industries Ltd, Lillestöm

V Digernes

Department of Pathology, Norwegian Radium Hospital, Oslo

V Abeler

Laboratory of Electronmicroscopy and Morphometry, Institute for Cancer Research, Norwegian Radium Hospital, Oslo

A Reith the nasal mucosa. ${ }^{23}$ Nasal epithelial dysplasia has also been described in man and, almost without exception, these lesions have been observed in occupations with a known increased incidence of nasal cancer such as nickel workers ${ }^{6-8}$ and furniture workers. ${ }^{910}$ Considerable evidence exists that these lesions should be considered as preneoplastic. ${ }^{11}$ Screening for dysplasia of the nasal mucosa therefore seems to be a sensitive method for assessing any possible risk from formaldehyde.

In the present study we have investigated, by means of nasal epithelial biopsies, whether nasal epithelial dysplasia is present in workers occupationally exposed to formaldehyde. Moreover, we have evaluated the significance of rhinoscopical examinations and recorded subjective nasal complaints.

\section{Material and methods}

Workers employed at a chemical company, located just outside Oslo, that produces formaldehyde and formaldehyde resins were asked to take part in this study. Since its inception in 1950 the production process has undergone several changes, resulting in a decrease of atmospheric formaldehyde. High exposure concentrations were experienced during the 1950 s and 1960s. During the past five years

Table 1 Grading of intensity to formaldehyde exposure

\begin{tabular}{|c|c|c|c|}
\hline Group & Description of exposure & $\begin{array}{l}\text { Airborne } \\
\text { concentration } \\
\text { of formaldehyde }\end{array}$ & $\begin{array}{l}\text { No of } \\
\text { workers } \\
\text { exposed }\end{array}$ \\
\hline 1 & $\begin{array}{l}\text { Occasional exposure (not } \\
\text { daily) up to level of } \\
\text { olfactory detection }\end{array}$ & & 0 \\
\hline 2 & $\begin{array}{l}\text { Not daily, but frequent } \\
\text { exposure exceeding the } \\
\text { level of irritation }\end{array}$ & $0.5-2 \mathrm{ppm}$ & 12 \\
\hline 3 & $\begin{array}{l}\text { Daily exposure up to } \\
\text { level of olfactory } \\
\text { detection }\end{array}$ & & 17 \\
\hline 4 & $\begin{array}{l}\text { Daily exposure } \\
\text { above the level of } \\
\text { irritation }\end{array}$ & $>2 \mathrm{ppm}$ & 5 \\
\hline 5 & $\begin{array}{l}\text { Daily exposure inducing } \\
\text { discomfort }\end{array}$ & & 3 \\
\hline
\end{tabular}

The level of olfactory detection is about $0.05-1.0 \mathrm{ppm}$ formaldehyde. Concentrations of $0 \cdot 1-3.0 \mathrm{ppm}$ causes irritation of the conjunctiva, nose, and pharynx. Discomfort increases with higher concentrations and few tolerate exposure exceeding 4-5 ppm for more than 10-20 minutes. At concentrations of 10-20 ppm breathing becomes difficult. Exposure above 20 ppm may cause pulmonary oedema. ${ }^{12-14}$ 
systematic measurements of atmospheric formaldehyde have been performed in various parts of the workplace. Exposure before 1980 was assessed by the plant health officer according to knowledge of the production process, recent measurements, and previous and present subjective sensations experienced by the workers. The level of exposure to which the workers presumably had been exposed was accordingly divided into five groups (table 1).

\section{SUBJECTS}

Thirty seven workers, half the workforce occupationally exposed to formaldehyde, volunteered to take part in the study. The control group consisted of 37 age matched subjects without overt nasal disease or occupations with known or suspected relations to nasal cancer. The controls were selected from the office staff of two chemical industries in Oslo, laboratory personnel at the Norwegian Radium Hospital, and outpatients at the ear, nose, and throat department, National Hospital, Oslo.

Table 2 shows the mean age and range, and duration of exposure. All participants were interviewed using a questionnaire containing detailed information about their occupational history, smoking habits, previous and present nasal complaints, and symptoms suggesting nasal allergy. Workers who had stopped smoking for less than a year before the examination were considered as smokers.

\section{COLLECTION OF SAMPLES}

After the application of local anaesthesia (tetracaine $2 \%$, adrenaline $0 \cdot 1 \%$ ) to the mucosal surface for about five minutes, biopsy specimens were taken from the anterior curvature of the middle turbinate of the nasal cavity that was judged to have the best air flow. ${ }^{6}$ The specimens were fixed in $4 \%$ buffered
Table 2 Mean age and duration of exposure

\begin{tabular}{lllllll}
\hline & & \multicolumn{2}{l}{ Age } & & \multicolumn{2}{c}{ Years employed } \\
& No & Mean & Range & & Mean & Range \\
\hline Exposed & 37 & 51 & $27-66$ & 20 & $3-36$ \\
Controls & 37 & 49 & $35-66$ & - & \\
\hline
\end{tabular}

formaldehyde, processed by routine methods, and the sections stained with haematoxylin and eosin.

\section{HISTOLOGICAL EXAMINATION}

All sections were examined independently by two of the authors (VA and MB) without access to clinical or occupational information. The histological classification and scoring of the epithelial changes were performed according to previous studies. ${ }^{679}$ The different types of epithelia are shown in figs $1-5$ and the scores given to each type in table 3 . Specimens showing more than one type of epithelium were graded according to the highest score.

\section{RHINOSCOPICAL FINDINGS}

The rhinoscopical appearance of the nasal mucosa

Table 3 Types of nasal epithelium and histological score

\begin{tabular}{ll}
\hline Types of epithelia & $\begin{array}{l}\text { Histological } \\
\text { score }\end{array}$ \\
\hline $\begin{array}{l}\text { Pseudostratified columnar epithelium } \\
\text { Stratified cuboidal epithelium }\end{array}$ & 0 \\
$\begin{array}{l}\text { Mixed stratified cuboidal/stratified } \\
\text { squamous epithelium }\end{array}$ & 1 \\
$\begin{array}{l}\text { Stratified squamous epithelium, } \\
\text { non-keratinising }\end{array}$ & 2 \\
$\begin{array}{c}\text { Stratified squamous epithelium, } \\
\text { keratinising }\end{array}$ & 3 \\
Dysplasia & 4 \\
\hline
\end{tabular}

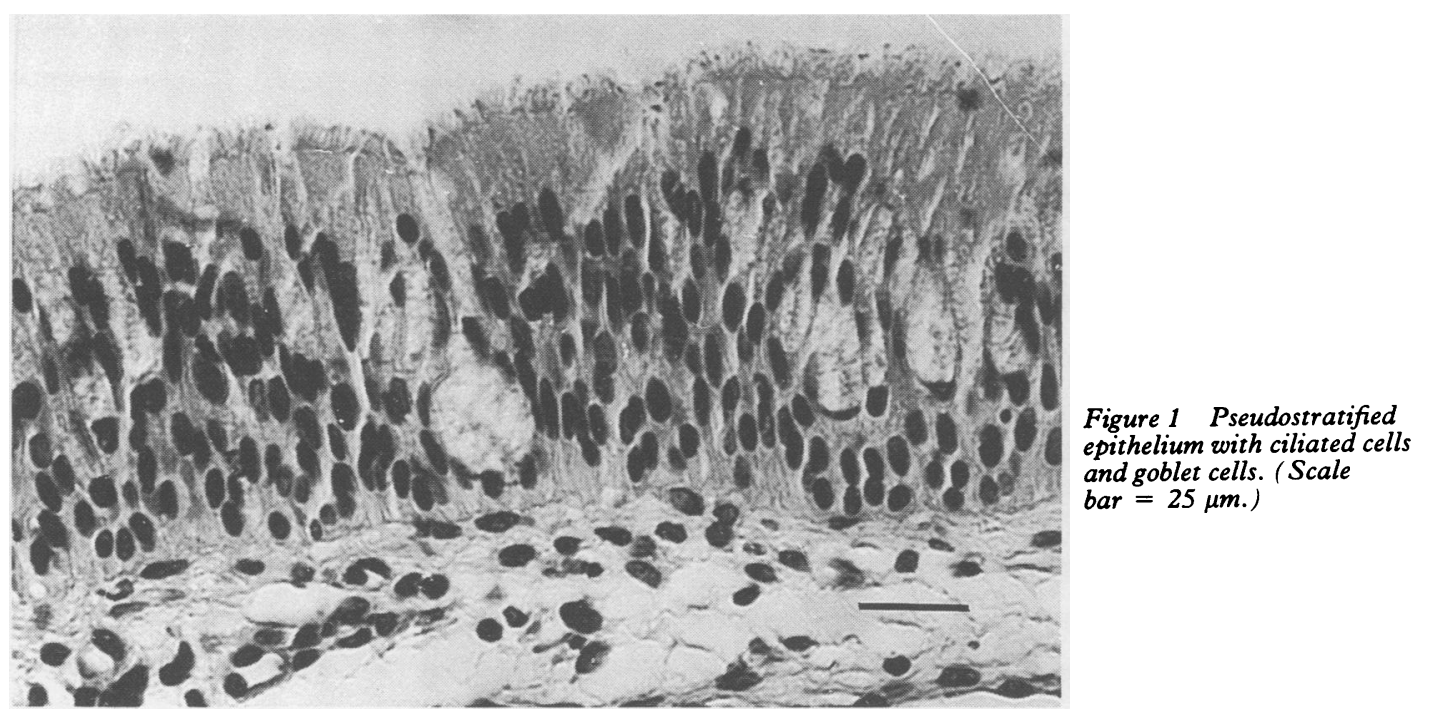




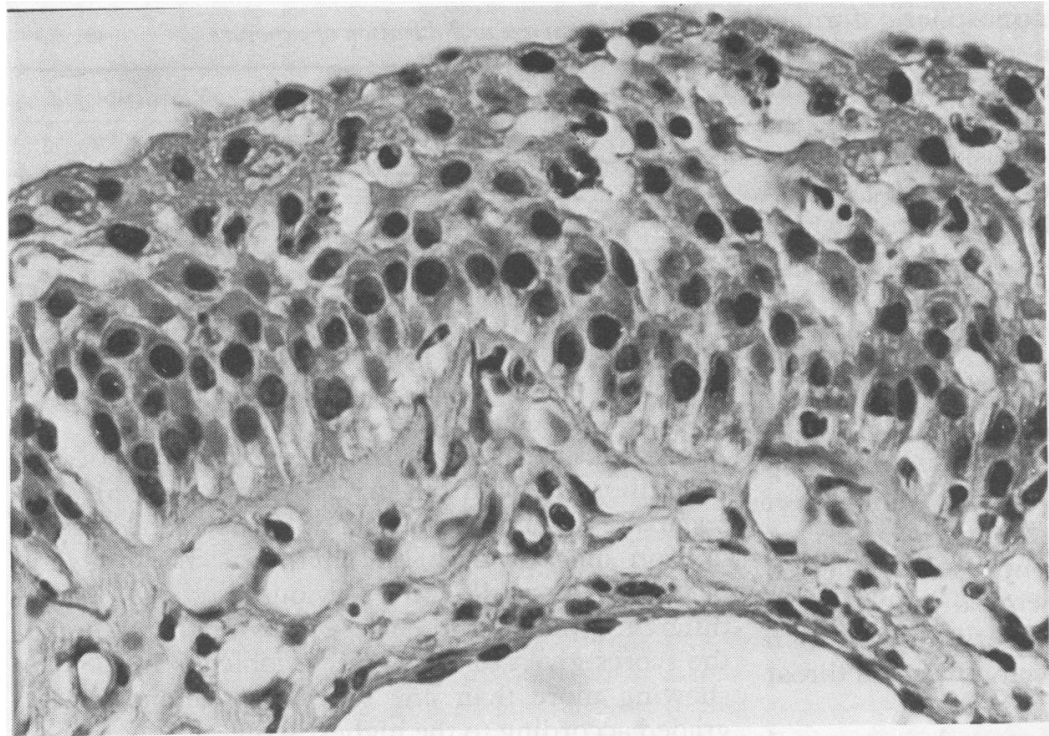

Figure 2 Stratified cuboidal epithelium composed of several layers of cuboidal cells and lacking ciliated cells. (Magnification as in fig 1.)

was scored according to the presence of the following characteristics: no abnormalities: 0 , hyperplastic nasal mucosa: 1 , and polypoid nasal mucosa: $2 .{ }^{9}$

\section{STATISTICS}

The Wilcoxon rank sum test was used to compare the histological findings in the two groups and to evaluate whether smoking, age, and duration and degree of exposure influenced the histological findings. The Chi-squared test was used to compare the rhinoscopical findings and subjective complaints.

\section{Results}

The groups did not differ as to environmental influences, smoking habits, and previous nasal disease. Table 4 shows that the degree of metaplastic alterations was more pronounced among the exposed workers than the controls, giving mean histological scores of 1.9 and 1.4 respectively $(p>0.05)$. Three

Table 4 Distribution of the histological score of exposed and control groups

\begin{tabular}{lllllllll}
\hline & & \multicolumn{1}{c}{ Histological score } \\
\cline { 3 - 8 } & No & 0 & 1 & 2 & 3 & 4 & 5 & Mean \\
\hline Exposed & 37 & 3 & 16 & 5 & 9 & 1 & 3 & $1 \cdot 9$ \\
Controls & 37 & 5 & 17 & 10 & 5 & 0 & 0 & $1 \cdot 4$ \\
\hline
\end{tabular}

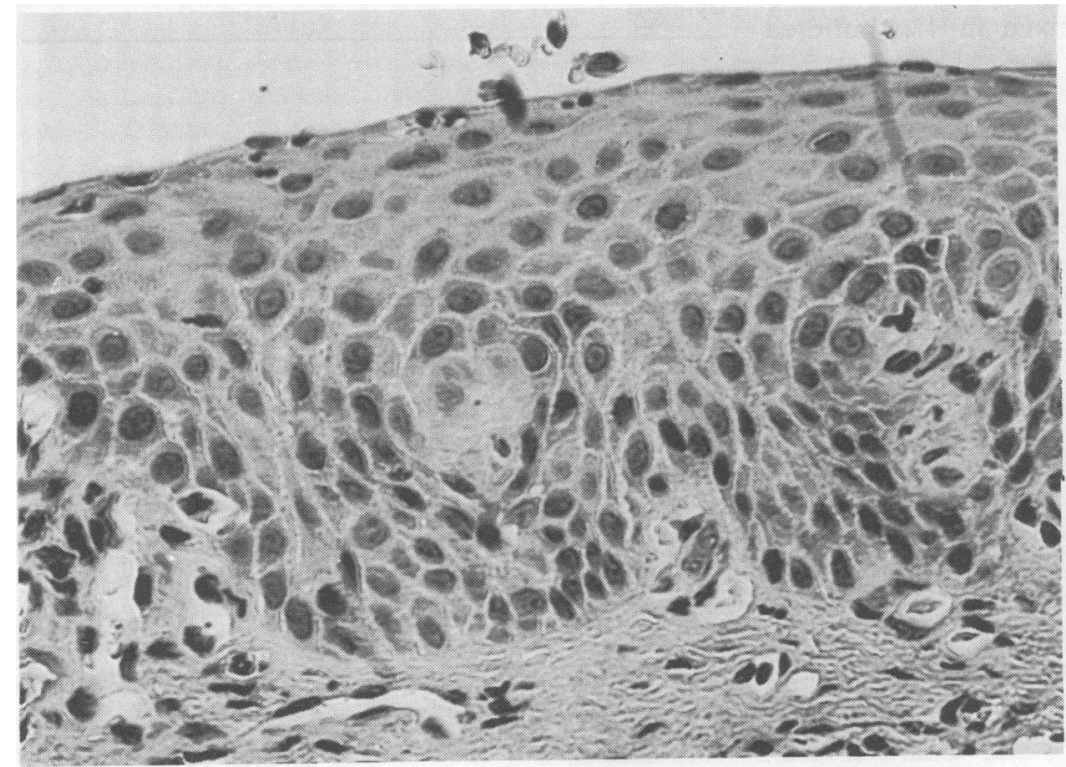

Figure 3 Mixed stratified cuboidal/stratified squamous epithelium consisting of several layers of cuboidal cells covered by a thin layer of flattened cells. (Magnification as in fig 1.) 


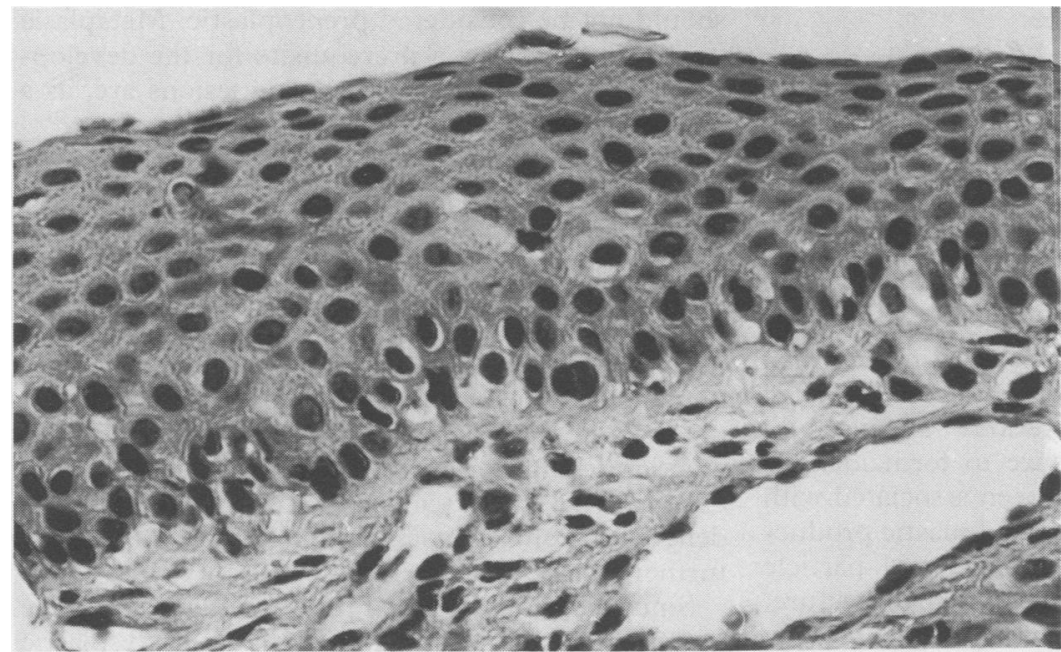

Figure 4 Stratified squamous epithelium with several layers of squamous cells overlying cells with distinct cell borders. (Magnification as in fig 1.)

cases of epithelial dysplasia, all of the squamous type, were observed in the formaldehyde group. These workers had been exposed daily to formaldehyde at concentrations ranging from 0.5 to $2 \mathrm{ppm}$ (group 3 ) for more than 22 years. Two of the exposed workers had previously been exposed to wood dust for some years and three were still exposed to some wood dust; none of these had epithelial dysplasia. The histological scores were somewhat higher among smokers than non-smokers, the scores further increased with age, degree, and duration of exposure, but the differences did not reach statistical significance.

Table 5 shows the rhinoscopical findings. The incidence of hyperplastic nasal mucosa was higher in the exposed than in the control group but the difference was not statistically significant. The incidence of subjective nasal complaints was considerably higher in the exposed subjects $(p<0.01)$ (table 6).

\section{Discussion}

Formaldehyde is ubiquitous and the background

Table 5 Rhinoscopical findings in exposed and control groups

\begin{tabular}{llll}
\hline & Normal & $\begin{array}{l}\text { Hyperplastic } \\
\text { nasal mucosa }\end{array}$ & $\begin{array}{l}\text { Polypoid } \\
\text { nasal mucosa }\end{array}$ \\
\hline Exposed & 28 & 9 & 0 \\
Controls & 33 & 4 & 0 \\
\hline
\end{tabular}

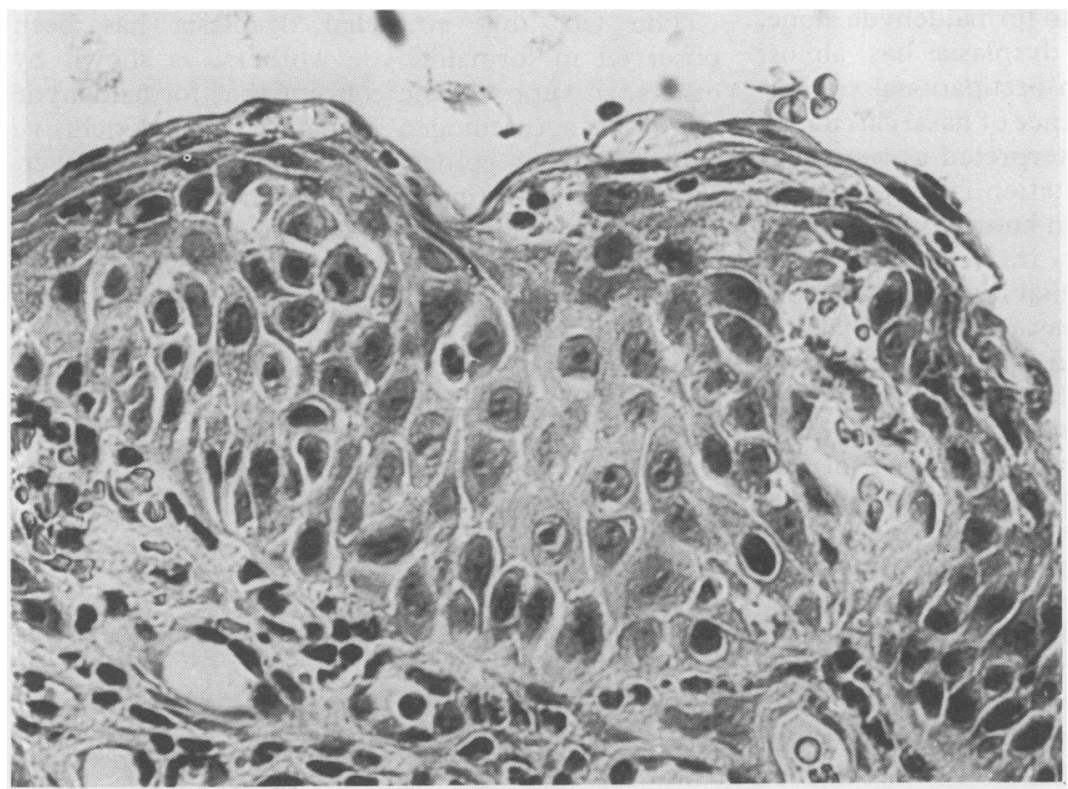

Figure 5 Dysplasia of the squamous type with nuclear and cellular pleomorphism and partial loss of polarity. (Magnification as in fig 1.) 
Table 6 Subjective nasal complaints

\begin{tabular}{llllll}
\hline & $\begin{array}{l}\text { Total } \\
\text { No }\end{array}$ & $\begin{array}{l}\text { Subjects } \\
\text { with } \\
\text { complaints }\end{array}$ & $\begin{array}{l}\text { Recurrent } \\
\text { epistaxis }\end{array}$ & $\begin{array}{l}\text { Nasal } \\
\text { stenosis }\end{array}$ & Irritation \\
\hline Exposed & 37 & $16^{\star}$ & 5 & 7 & 5 \\
Controls & 37 & 2 & 2 & 0 & 0 \\
\hline
\end{tabular}

${ }^{\star} \mathrm{p}<0.01$.

exposure level is about $0.01 \mathrm{ppm} .{ }^{13}$ Unlike most other carcinogens, formaldehyde is also a normal constituent of living cells. ${ }^{15}$ It is also a component of cigarette smoke at concentrations as high as $40 \mathrm{ppm} .{ }^{15}$ Occupational exposure to formaldehyde exceeding values of $1 \mathrm{ppm}$ has been associated with formaldehyde production, resin and plastic production, clothing manufacture, plywood and particle board production, and wood furniture manufacture. It is also associated with embalming and pathology and biology laboratories. ${ }^{5}$ It is estimated that in the United States about $1.6 \mathrm{~m}$ people are occupationally exposed to formaldehyde. ${ }^{4}$ Concern has also been expressed on the possible health effects of formaldehyde emission from products such as plywood panelling and insulation with formaldehyde foam. ${ }^{16}$

Many epidemiological studies have been performed in the past years. ${ }^{5}$ Among these, only three case-control studies have suggested an association between exposure to formaldehyde and nasal cancer. ${ }^{17-19}$ In two of these studies the subjects had also been exposed to wood dust, a known nasal carcinogen ${ }^{20}$; in the third a possible association was found in printers. Accordingly, there was no exposure to known or suspected carcinogens and there is no clear evidence of increased frequency of nasal cancer due to exposure to formaldehyde alone.

The fact that epithelial dysplasia has almost exclusively been described in occupational settings with a known increased incidence of nasal carcinoma suggests that it should be interpreted as a preneoplastic lesion. ${ }^{\text {"T }}$ This interpretation is supported by morphological similarities with known preneoplastic lesions in the lower respiratory tract.

Assuming that nasal epithelial dysplasia is a preneoplastic lesion and that it has a higher prevalence than carcinoma, its presence in evaluating a possible carcinogenic risk becomes clear. In addition to a higher incidence of squamous metaplasia, we found three cases of nasal epithelial dysplasia of the squamous type among workers with prolonged daily exposure at concentrations between 0.5 and $2 \mathrm{ppm}$. The study is, however, too small to draw any conclusions as to the significance between the histological findings and the duration or degree of exposure. Metaplastic changes themselves are generally considered as non-specific, being induced by extrinsic factors such as temperature, humidity, dust, and chemicals; they also increased with age and should not be considered preneoplastic. Metaplasia might, however, be a prerequisite for the development of dysplasia since dysplastic lesions are, as a rule, found within areas of squamous metaplasia. ${ }^{21}$

Only limited areas of the nasal mucosa may be examined with a biopsy. The anterior curvature of the middle turbinate was chosen for several reasons. This region is easily identified and reached with biopsy forceps. Moreover it is believed that tumours favour this region ${ }^{822}$ because particles have a tendency to deposit here. ${ }^{23}$ In this context it should be noted that in experimental studies the most pronounced degree of epithelial alterations have been seen in the anterior part of the nasal cavity. ${ }^{3}$ Both in experimental animals and in man exposure to formaldehyde inhibits mucocilliary function, which may further enhance its adverse effects. ${ }^{24} 25$

Since only small areas of the nasal mucosa may be examined histologically the number of dysplastic lesions found in this study cannot be expected to reflect the real prevalence of dysplasia. Based on follow up studies in nickel workers it has been calculated that the real incidence of dysplasia is two to four times that detected in single biopsies. ${ }^{6}$ Accordingly, the biopsy method is of limited value for identifying an individual risk but appears to be useful in identifying and possibly also monitoring groups of people exposed to known or suspected nasal carcinogens. ${ }^{6-10}$ With cytological methods a larger area of the nasal mucosa may be examined. A recent study suggests that a higher incidence of epithelial alterations may be detected with this method than with small biopsies. ${ }^{25}$ The cytological method may therefore be the method of choice in future screening for nasal epithelial alterations. ${ }^{1126}$

The fact that epithelial dysplasia has been observed in formaldehyde workers, as shown by others, ${ }^{27}{ }^{28}$ supports the concept that formaldehyde might be a carcinogen in man. The inconclusive evidence from epidemiological studies, however, indicates that formaldehyde in the concentrations reached in occupational settings seldom induces nasal cancer. Formaldehyde may, however, interact with other carcinogens or act as a promoter.

This study was supported by the Norwegian Cancer Society.

Requests for reprints to: $\mathrm{Dr} M$ Boysen, Department of Otolaryngology, Rikshospitalet, 0027 Oslo 1, Norway.

1 Albert RE, Sellakumar AR, Laskin S, Kuschner M, Nelson N, Snyder CA. Gaseous formaldehyde and hydrogen chloride induction of nasal cancer in the rat. $J$ Natl Cancer Inst 1982;68:597-603.

2 Swenberg JA, Kerns WD, Mitchell RI, Gralla EJ, Pavkov KL. Induction of squamous cell carcinomas of the rat nasal cavity by inhalation exposure to formaldehyde vapor. Cancer Res 1980:40:3398-402. 
3 Kerns WD, Pavkov KL, Donofrio DJ, Gralla EJ, Swenberg JA. Carcinogenicity of formaldehyde in rats and mice after longterm inhalation exposure. Cancer Res 1983;43:4382-92.

4 Blair A, Walrath J, Malker H. Review of epidemiologic evidence regarding cancer and exposure to formaldehyde. Advances in Chemical Services 1985;210:263-73.

5 Nelson N, Levine RJ, Albert RE, et al. Contribution of formaldehyde to respiratory cancer. Environ Health Perspect 1986;70:23-35.

6 Boysen M, Solberg LA, Andersen I, Hogetveit AC, Torjussen W. Nasal histology and nickel concentration in plasma and urine after improvements in the work environment at a nickel refinery in Norway. Scand $J$ Work Environ Health 1982;8:283-9.

7 Boysen M, Solberg LA, Torjussen W, Poppe S, Högetveit AC Histological changes, rhinoscopical findings and nickel concentrations in plasma and urine in retired nickel workers. Acta Otolaryngol (Stockh) 1984;97:105-15.

8 Torjussen W, Solberg LA, Högetveit AC. Histopathological changes of the nasal mucosa in active and retired nickel workers. Br J Cancer 1979;40:568-80.

9 Boysen M, Solberg LA. Changes in the nasal mucosa of furniture workers. A pilot study. Scand J Work Environ Health 1982;8:273-82.

10 Boysen M, Voss R, Solberg LA. The nasal mucosa in softwood exposed furniture workers. Acta Otolaryngol (Stockh) 1986;101:501-8.

11 Reith A, Boysen M, Voss R. Environmental pathology of the upper respiratory tract. In: Gnepp DR, ed. Pathology of the head and neck. New York: Churchill Livingstone, 1988: 315-34.

12 Ballenger JJ. Some effects of formaldehyde on the upper respiratory tract. Laryngoscope 1984;94:1411-3.

13 Clary JJ. Formaldehyde risk analysis. Advances in Chemical Services 1985;210:341-55.

14 Triebig G, Valentin H. Gesundheitsrisiken durch Formaldehyd. Eine arbeitsmedizinische Bestandsaufnahme. Pathologie 1985;6:64-70.

15 Hileman B. Formaldehyde: assessing the risk. Environmental Science Technology 1984;18:218-21.

16 Vaughan TL, Strader C, Davis S, Daling JR. Formaldehyde and cancers of the pharynx, sinus and nasal cavity: II. Residential exposures. Int J Cancer 1986;38:685-8.

17 Hayes RB, Raatgever JW, de Bruyn A, Gerin M. Cancer of the nasal cavity and paranasal sinuses, and formaldehyde exposure. Int J Cancer 1986;37:487-92.

18 Olsen JH, Jensen SP, Hink M, Faurbo K, Breum NO, Jensen $O M$. Occupational formaldehyde exposure and increased nasal cancer risk in man. Int $J$ Cancer 1984;34:639-44.

19 Roush GC, Walrath J, Stayner LT, Kaplan SA, Flannery JT, Blair A. Nasopharyngeal cancer, sinonasal cancer, and occupations related to formaldehyde: a case-control study. $J$ Natl Cancer Inst 1987;79:1221-4.

20 International Agency for Research on Cancer. Monographs on the evaluation of the carcinogenic risk of chemicals to humans. Vol 25. Wood, leather and some associated industries. Lyon: IARC, 1981.

21 Boysen $M$, Reith $A$. The surface structure of the human nasal mucosa. II. Metaplasia, dysplasia and carcinoma in nickel workers. A correlated study by scanning/transmission electron and light microscopy. Virchows Arch (Cell Pathol) 1982;40:295-309.

22 Virtue JA. The relationship between refining of nickel and cancer of the nasal cavity. Canadian Journal of Otolaryngology 1972;1:37-42.

23 Hadfield EH. A study of adenocarcinoma of the paranasal sinuses in woodworkers in the furniture industry. Ann $R$ Coll Surg Engl 1970;46:301-19.

24 Andersen I, Molhave L. Controlled human studies with formaldehyde. In: Gibson JF, ed. Formaldehyde toxicity. New York: Hemisphere, 1983:154-65.

25 Morgan KT, Gross EA, Patterson DL. Distribution, progression, and recovery of acute formaldehyde-induced inhibition of nasal mucocilliary function in F-344 rats. Toxicol Appl Pharmacol 1986;86:448-56.

26 Voss R, Reichborn-Kjennerud S, Abeler V, Reith A. Development of brush cytology for detection of metaplastic and dysplastic nasal mucosa lesions: a preliminary report. Acta Otolaryngol (Stockh) 1986;101:299-304.

27 Edling C, Hellquist H, Ödkvist L. Occupational exposure to formaldehyde and histopathological changes in the nasal mucosa. Br J Ind Med 1988;45:761-5.

28 Holmström M, Wilhelmsson B, Hellquist H, Rosén G. Histological changes in the nasal mucosa in persons occupationally exposed to formaldehyde alone and in combination with wood dust. Acta Otolaryng (Stockh) 1989;107:120-9.

Accepted 18 March 1989 